\title{
Materials Flow of Indium in the United States in 2008 and 2009
}

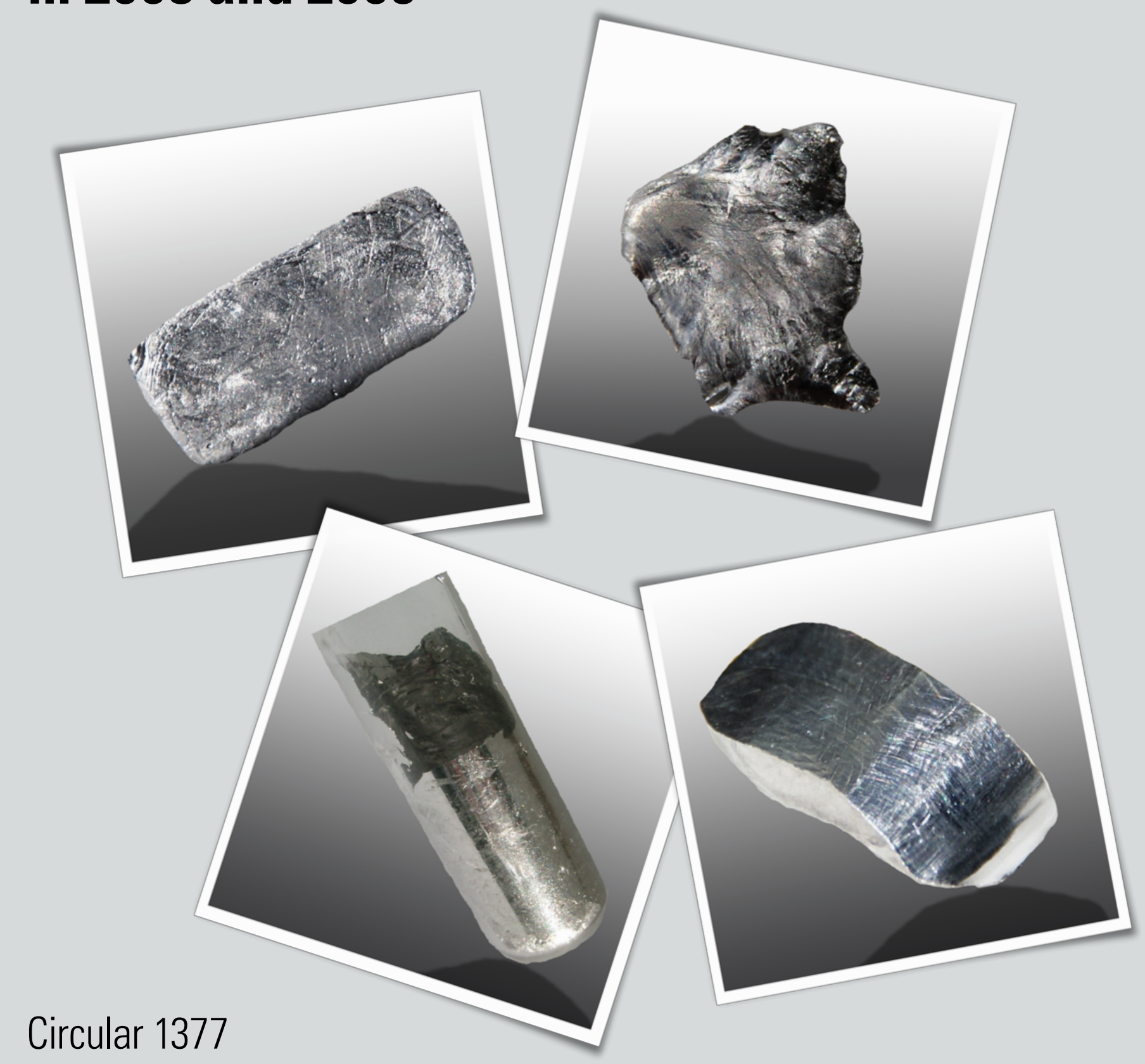

U.S. Department of the Interior

U.S. Geological Survey 




Cover (clockwise, from top left). $A$, Indium ingot (modified from Hi-Res Images of Chemical Elements, http://images-of-elements.com/ indium.php); $B$, molten indium (modified from Hi-Res Images of Chemical Elements, http://images-of-elements.com/indium.php); $C$, indium in a test tube (modified from Wikipedia, http://en.wikipedia.org/wiki/Indium); and $D$, freshly cut indium (modified from Hi-Res Images of Chemical Elements, http://images-of-elements.com/indium.php). 


\section{Materials Flow of Indium in the United States in 2008 and 2009}

By Thomas G. Goonan

Circular 1377

U.S. Department of the Interior

U.S. Geological Survey 


\section{U.S. Department of the Interior \\ KEN SALAZAR, Secretary \\ U.S. Geological Survey \\ Marcia K. McNutt, Director}

\section{U.S. Geological Survey, Reston, Virginia: 2012}

For more information on the USGS - the Federal source for science about the Earth, its natural and living resources, natural hazards, and the environment, visit http://www.usgs.gov or call 1-888-ASK-USGS.

For an overview of USGS information products, including maps, imagery, and publications, visit http://www.usgs.gov/pubprod

To order this and other USGS information products, visit http://store.usgs.gov

Any use of trade, product, or firm names is for descriptive purposes only and does not imply endorsement by the U.S. Government.

Although this report is in the public domain, permission must be secured from the individual copyright owners to reproduce any copyrighted materials contained within this report. 


\section{Contents}

Abstract
Introduction.
Structure of the Indium Industry in the United States
Production Processes
Stockpiles.
Pecycling
Outlook
References Cited.

\section{Figures}

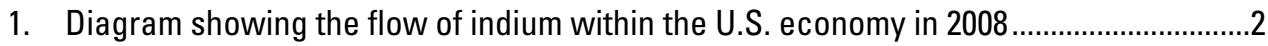

2. Diagram showing the flow of indium within the U.S. economy in 2009 ...............................

3. Bar chart showing world production of indium from zinc concentrates

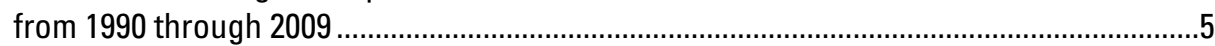

4. Bar chart showing U.S. consumption of indium metal from

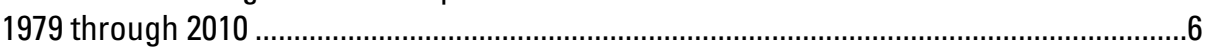

5. Chart showing U.S. prices of indium metal from 1950 through 2010 ................................

\section{Table}

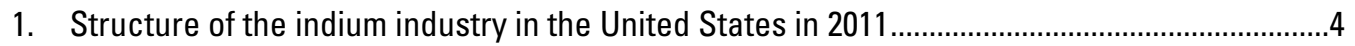




\section{Conversion Factors}

Temperature in degrees Celsius $\left({ }^{\circ} \mathrm{C}\right)$ may be converted to degrees Fahrenheit $\left({ }^{\circ} \mathrm{F}\right)$ as follows: ${ }^{\circ} \mathrm{F}=\left(1.8 \mathrm{x}^{\circ} \mathrm{C}\right)+32$.

Temperature in degrees Fahrenheit $\left({ }^{\circ} \mathrm{F}\right)$ may be converted to degrees Celsius $\left({ }^{\circ} \mathrm{C}\right)$ as follows: ${ }^{\circ} \mathrm{C}=\left({ }^{\circ} \mathrm{F}-32\right) / 1.8$.

Vertical coordinate information is referenced to the North American Vertical Datum of 1988 (NAVD 88).

Horizontal coordinate information is referenced to the North American Datum of 1983 (NAD 83). 


\title{
Materials Flow of Indium in the United States in 2008 and 2009
}

\author{
By Thomas G. Goonan
}

\section{Abstract}

Indium is a material that has many applications. It is used by anyone who watches television or views a computer screen. It is found in solar energy arrays and in soldering applications that are required to be lead free. In 2009, about 550 metric tons (t) of indium metal was produced from primary sources worldwide; it was estimated that the United States consumed about $110 \mathrm{t}$ of indium metal (20 percent of world primary production). However, when imports of consumer products that contain indium are considered, the United States consumed about $200 \mathrm{t}$ of indium (36 percent of world primary production).

When one considers the recovery from the low-efficiency sputtering process that coats indium-tin oxide onto glass and other surfaces, the recycling rate (within the manufacturing process that uses indium-tin oxide in flat panel displays) approaches 36 percent. However, indium recovery from old scrap generated from end-of-life consumer products is not sufficiently economic to add significantly to secondary production.

Between 1988 and 2010, indium prices averaged \$381 per kilogram (in constant 2000 dollars). However, prices have been quite volatile (deviating from the average of $\$ 381$ per kilogram by $\pm \$ 199$ per kilogram, a 52 percent difference from the average), reflecting short-term disequilibrium of supply and demand but also responsiveness of supply to demand. The dynamics of zinc smelting govern the primary supply of indium because indium is a byproduct of zinc smelting. Secondary indium supply, which accounts for about one-half of total indium supply, is governed by indium prices and technological advances in recovery. Indium demand is expected to grow because the number and volume of cutting edge technology applications that depend on indium are expected to grow.

\section{Introduction}

Indium is a very soft metal that has many uses in cutting edge technology (high-tech) applications, including as a transparent conductive coating to glass substrates (such as flat panel displays), in semiconductors, light-emitting diodes (LEDs) and laser diodes, and alkaline batteries and in cryogenics and ultra-high vacuum applications. The properties of indium that make it attractive include low-temperature malleability and ductility (for cryogenic applications), low melting point (for solder alloys that are free of lead and mercury), self-attraction (for cold weldability and bonding of unlike substances coated with indium), electrical conductance with light-transparency (for flat panel displays used by computers, handheld electronics, and televisions) in the form of iron-tin oxide (ITO), and infrared light reflectance (for architectural and photovoltaic glass used in buildings, automobiles, and aircraft).

Flow data (production, consumption, trade, and recycling) for indium are not reported to as great an extent as for other mineral commodities. The flows reported here are presented with two significant digits because of the paucity of the underlying data. Appendix 1 details the assumptions that underlie the calculations.

In 2008, consumption of indium metal in the United States (fig. 1) was 130 metric tons (t), which was about 22 percent of the $600 \mathrm{t}$ of primary production of indium worldwide (Tolcin, 2011). When all indium sources are considered (alloys, chemicals, and ITO contained in consumer products, such as imported computers, monitors, and televisions), about $220 \mathrm{t}$ of indium was consumed in the United States in 2008, or roughly 37 percent of primary production of indium worldwide. The United States imported 100 percent of the indium it consumed, regardless of the form in which indium was consumed.

The flow patterns for indium in 2009 (fig. 2) were somewhat different from those in 2008, mostly with regard to the amounts and direction of flows into the supply of indium for semifabrication. In 2009, consumption of indium metal in the United States was $110 \mathrm{t}$, which was about 20 percent of the $550 \mathrm{t}$ of primary production of indium worldwide (Tolcin, 2011). When all indium sources are considered, it was estimated that about $200 \mathrm{t}$ of indium was consumed in the United States in 2009 , or roughly 36 percent of primary world indium production. The United States continued to import 100 percent of the indium it consumed in 2009.

The greatest use for indium (about 56 percent) is in formulation of ITOs (composition of 78 percent indium, 17.5 percent oxygen, and 4.5 percent tin), which are used to coat the glass or plastic substrates used in flat panel displays (FPDs) (Tolcin, 2011). The FPD market (as expressed in metric tons of materials) in the United States grew at an average annual rate of about 31 percent between 2004 and 2010; this corresponded to a growth in the consumption of indium for ITOs, caused primarily by increases in televisions sold (ICF International, 2011) and the increase in the average screen size. DisplaySearch (2009) projected that the average rate of FPD shipments from 2010 through 2015 would be 5 percent. The market grew by 7.3 percent in 2010 (ICF International, 2011). 


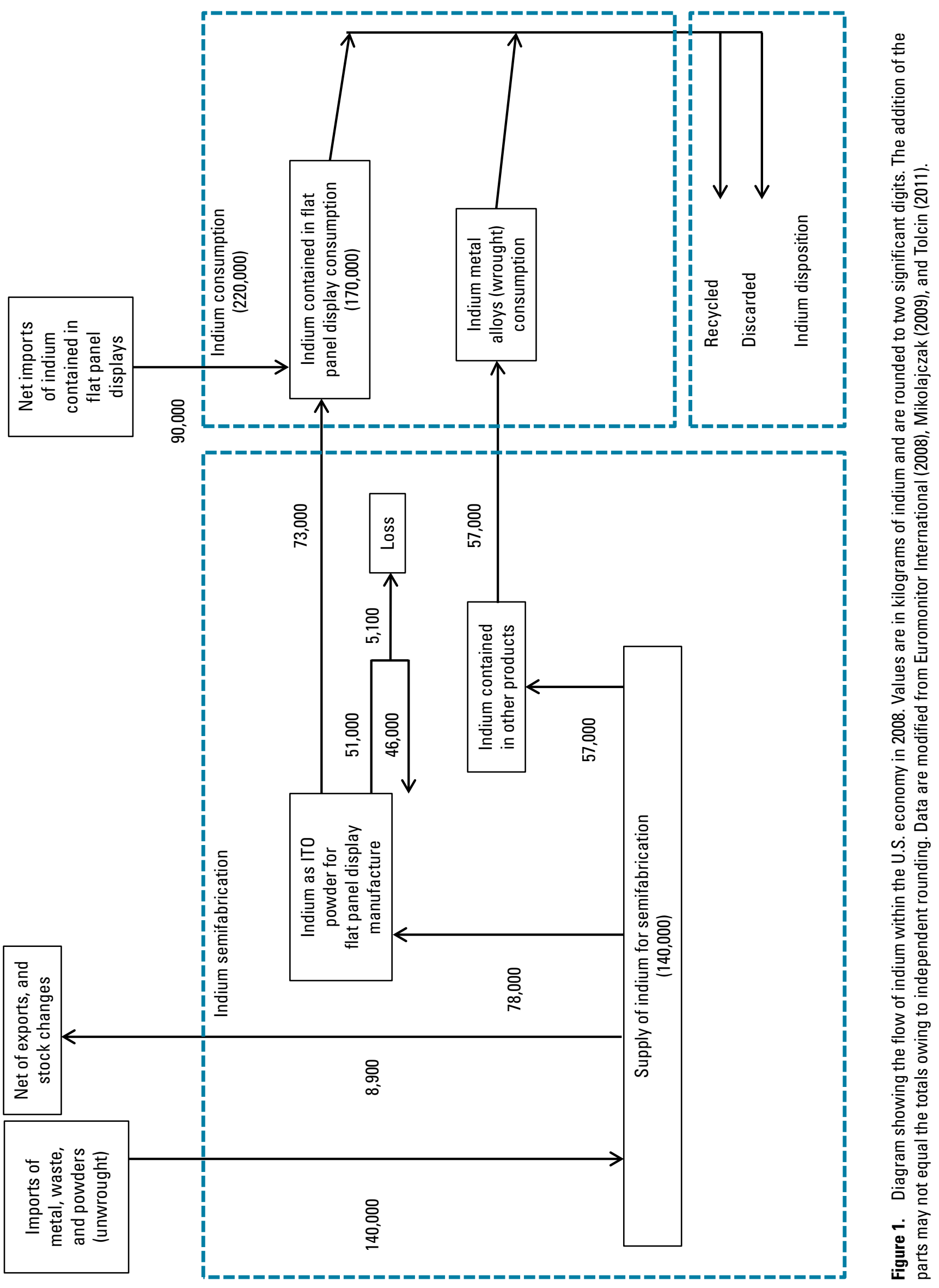




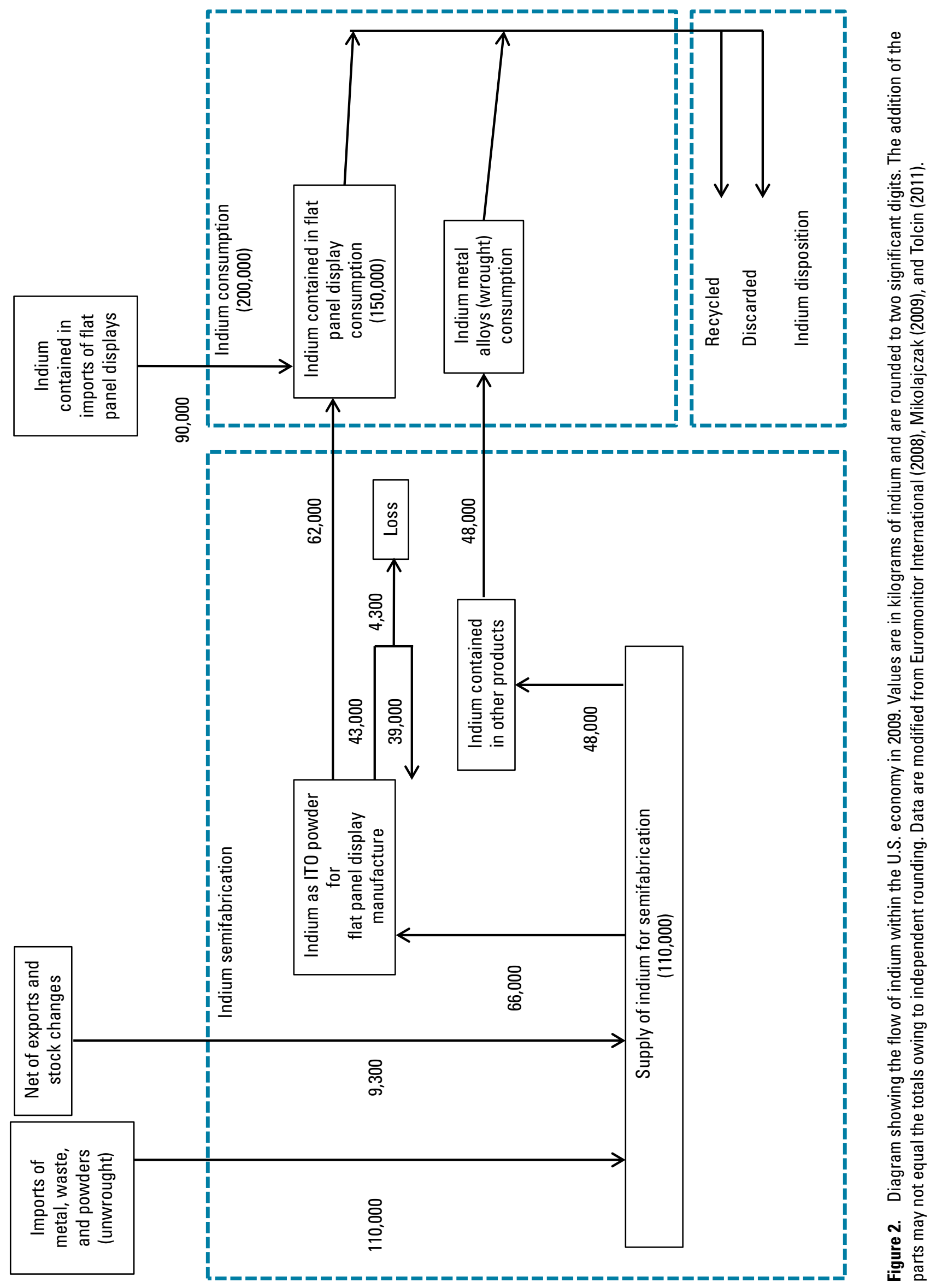




\section{Structure of the Indium Industry in the United States}

The indium manufacturing industry in the United States is entirely supported by imports of indium. The indium manufacturing industry produces high-purity indium metal, fusible alloys, ITO, and other indium chemicals (chlorides, hydroxides, oxides, sulfamates, and others). Production of indium metal in the United States in 2008 consisted of upgrading imported indium metal. Lower grade (99.97 percent) and standard-grade (99.99 percent) indium was imported and refined to purities of up to 99.9999 percent. Indium Corporation of America, Utica, New York, and Umicore Thin Film Products (a division of n.v. Umicore s.a.) accounted for the largest share of production of indium metal and products in the United States (Tolcin, 2011). Table 1 lists the companies that produced indium products in the United States in 2011.

\section{World Production}

Indium can be produced as a byproduct of tin and lead production; however, under present economic conditions, virtually all indium production is currently [2011] associated with zinc smelting. Figure 3 shows worldwide production of indium from zinc concentrates by country of origin from 1990 through 2009. For comparison, the annual average nominal price for indium is also depicted. From the data depicted in figure 3 , indium production appears to be occuring in steps, each about 5 years long.
1990-1994 Annual indium production averaged about 140 $\mathrm{t}$, and the nominal price of indium declined moderately the first 4 years of the cycle and more steeply the last year.

1995-1999 Annual indium production increased to average about $230 \mathrm{t}$, with the growth mostly attributed to increased production in China and countries in the "other" category. Between 1994 and 1995, world procuction increased by 65 percent, and prices increased by 172 percent, indicating strong demand for indium. Prices started a decreasing trend after 1995.

2000-2004 Annual production increased to average about $400 \mathrm{t}$, with the growth mostly attributed to China and Japan. The decreasing trend that started after 1995 continued through 2002 to the point where the nominal price for indium in 2002 was 32 percent lower that that in 1994, indicating that the added world capacity and production from 1995 through 2004 far outpaced demand for the period. In 2003, prices began to increase, and the increase continued in 2004 when they increased by 268 percent in a single year.

2005-2009 Annual production increased to average about $600 \mathrm{t}$, with the growth attributed to China and the Republic of Korea. Indium prices continued to increase dramatically (by about 798 percent) from the low in 2002 to a new high in 2005 , driven by demand for FPDs for televisions and computer monitors. From the time that production increased

Table 1. Structure of the indium industry in the United States in 2011

[Conn., Connecticut; Fla. Florida; ITO, iron-tin oxide; New York, N.Y., Pennsylvania, Pa.; Wis., Wisconsin]

\begin{tabular}{|c|c|c|c|}
\hline Company & Location & Indium product & Form \\
\hline $\begin{array}{l}\text { AIM Specialty Materials } \\
\text { http://www.aimspecialty.com/ }\end{array}$ & Cranston, R.I. & Alloys, chemicals, ITO, and metal & $\begin{array}{l}\text { Foil, pastes, preforms, ribbon, } \\
\text { seals, and wire. }\end{array}$ \\
\hline $\begin{array}{l}\text { Belmont Specialty Metals Inc. } \\
\text { http://www.belmontmetals.com/ }\end{array}$ & Brooklyn, N.Y. & Alloys & Solders and wire. \\
\hline $\begin{array}{l}\text { Exotech Inc. } \\
\text { http://www.exotech.com/ }\end{array}$ & Pompano Beach, Fla. & Alloys, ITO, and metal & Solids. \\
\hline $\begin{array}{l}\text { Indium Corporation of America } \\
\text { http://www.indium.com/ }\end{array}$ & Utica, N.Y. & Alloys, ITO, and metal & $\begin{array}{l}\text { Fluxes, preforms, solders, and } \\
\text { sputtering targets. }\end{array}$ \\
\hline $\begin{array}{l}\text { Materion Advanced Chemicals Inc. } \\
\text { http://materion.com/ }\end{array}$ & Milwaukee, Wis. & Vapor deposition materials & Sputtering targets. \\
\hline $\begin{array}{l}\text { MCP Metalspecialties Inc. } \\
\text { http://mcpmetspec.thomasnet.com/ }\end{array}$ & Fairfield, Conn. & Alloys, chemicals, ITO, and metal & Forms and powders. \\
\hline
\end{tabular}


in 2005, nominal prices for indium through 2009 have decreased (by about 52 percent from the 2005 high). In 2009, China dominated world production of indium with about 51 percent of the world's market share (Tolcin, 2011).

Companies in the United States have not produced indum metal from zinc concentrates since the early 1970s. However, there are companies that further refine imported, 99.97 percent indium to higher purity levels (Jorgenson and George, 2005).

\section{Production Processes}

Indium production processes are mostly proprietary. However, the steps for indium recovery from zinc concentrates can be described in general terms. Indium source materials include alloys from zinc or lead-and-zinc pyrometallurgical processing (smelting or calcining), dusts, fumes, residues, and slags. These materials may contain many elements that must be separated from the desired indium. The first step is to leach the materials with a weak acid (sulfuric or hydrochloric) solution. Indium and other metals will go into solution. Depending on the nature of the leach solution, selective precipitation through $\mathrm{pH}$-control or solvent extraction technologies can be used to concentrate the indium. Whatever the interim concentrated indium product, the final step is electrolytic refining to obtain high-purity, 99.9999 percent indium metal, which can be formed into ingot, powder, ribbon, shot, wire, and other shapes (Swarz-Schampera and Herzig, 2002; Alfantazi and Moskalyk, 2003; Lahtinen and others, undated).

As with most commodities, indium is available in nanoparticle formats. End uses for nanoparticle indium include inkjet printing, catalysts for chemical synthesis, gas sensing, and infrared attenuation.

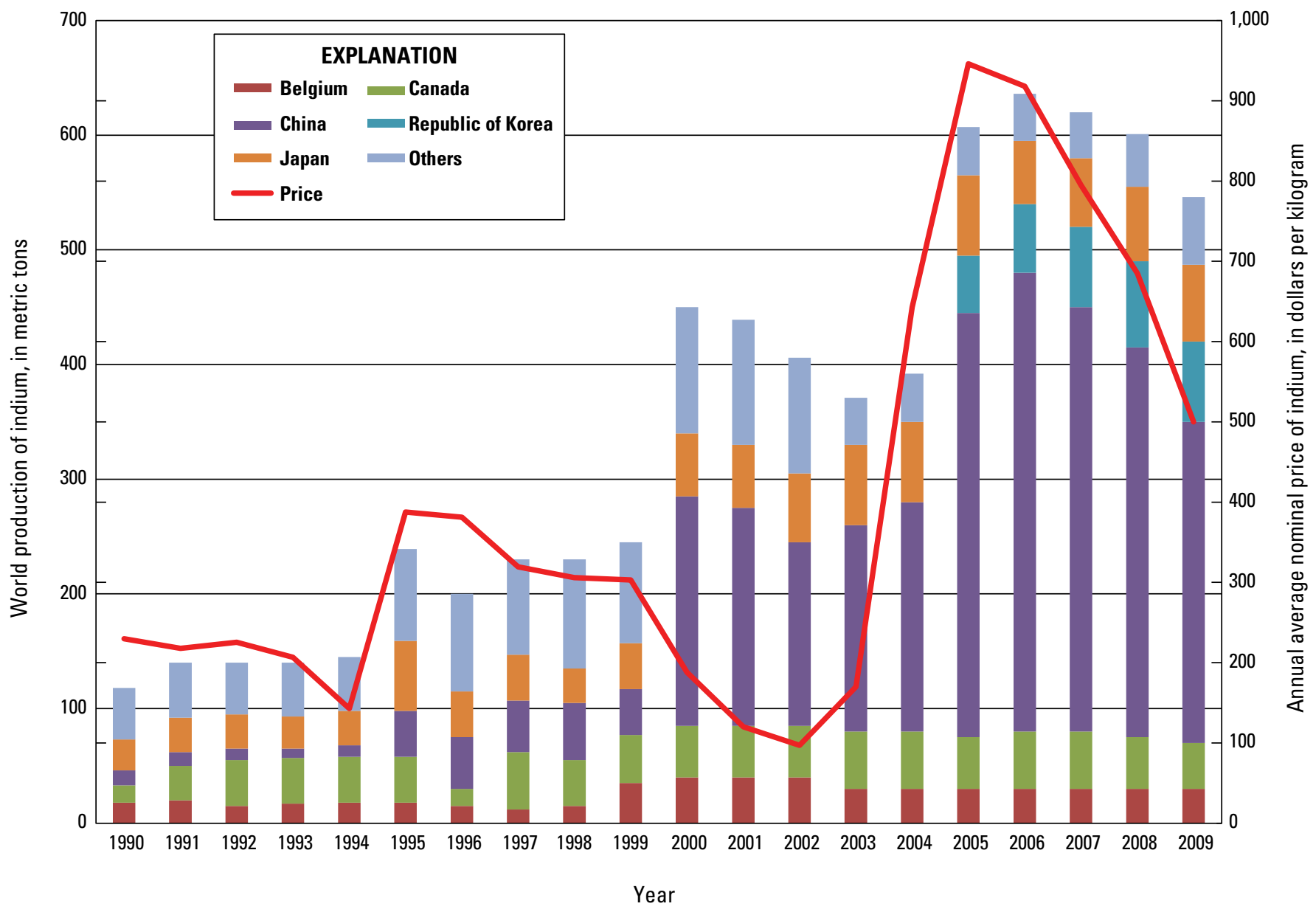

Figure 3. Bar chart showing world production of indium from zinc concentrates from 1990 through 2009. Values are in metric tons of indium metal. Not all material is refined in the country of origin. Data are from Jasinski (1990-1995), Brown (1996-2001a), George (2005), Carlin (2006), Callaghan and Carlin (2007), and Tolcin (2008-2011). 


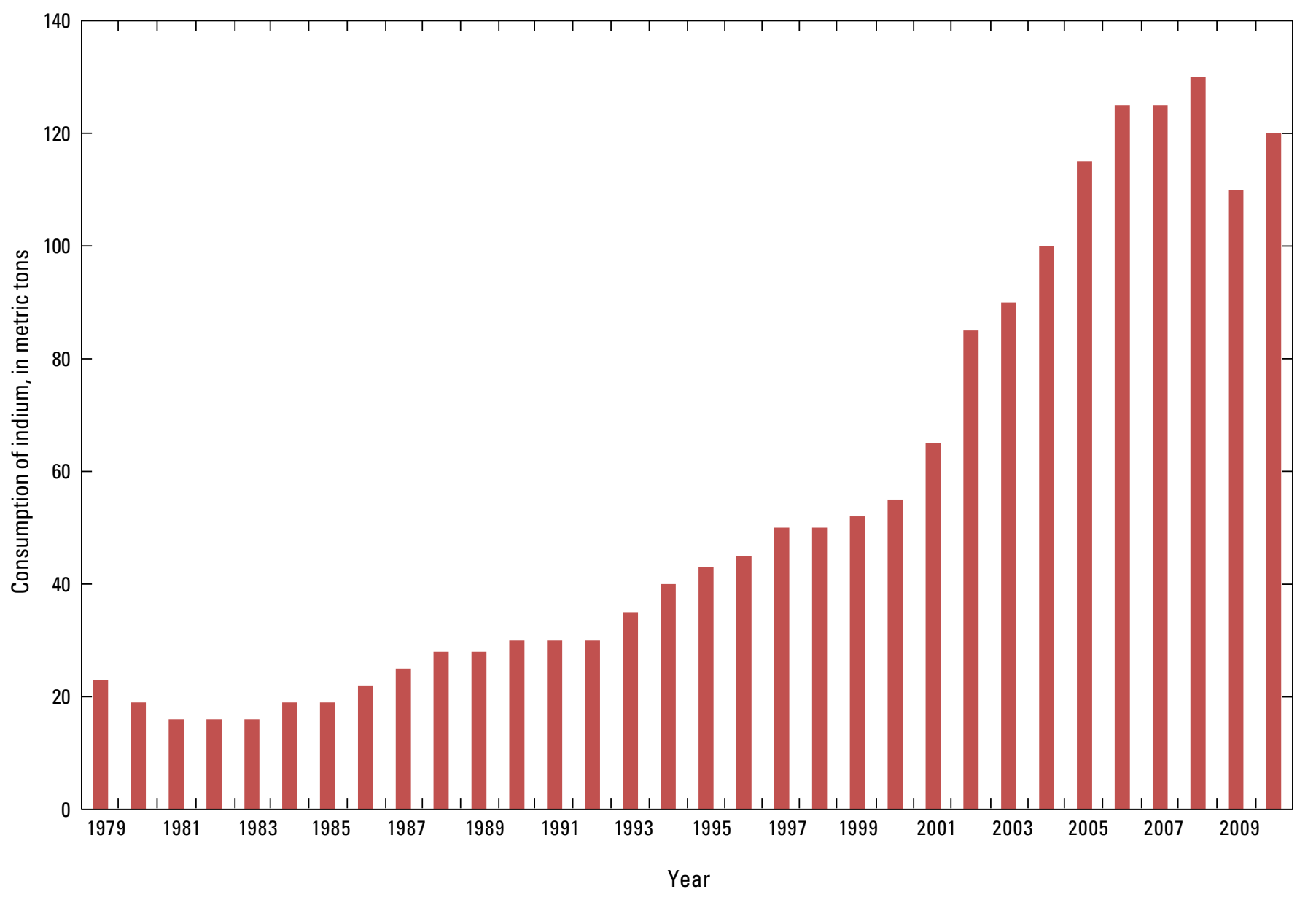

Figure 4. Bar chart showing U.S. consumption of indium metal from 1979 through 2010 . Values are in metric tons indium metal. Data are from DiFrancesco and others (2010).

\section{Stockpiles}

Some governments maintain stockpiles of indium. In December 2008, China's State Reserve Bureau (SRB) purchased $30 \mathrm{t}$ of indium ingots from Huludao Zinc Industry and was expected to continue stockpiling indium in the form of ingots (SMG Indium Resources Ltd., 2011).

In 2006, the Republic of Korea planned to launch a stockpile of 13 rare metals (including indium) and ferroalloys (SMG Indium Resources Ltd., 2011). In 2009, the Republic of Korea budgeted \$200 billion for the national metal stockpile, of which 20 percent was allocated for the procurement of minor metals, including indium (Tolcin, 2011).

In June 2009, the Government of Japan planned to purchase $60 \mathrm{t}$ of refined indium domestically through a public tender (Metal Bulletin, 2009). In 2010, Japan imported 417 t of indium, a 94 percent increase compared with the $215 \mathrm{t}$ of indium imported in 2009. This move has lead to speculation that Japan is involved with indium stockpiling (RareMetalsInvesting, 2011).

The National Defense Stockpile Center (NDSC) of the United States held stocks of indium, but the last of the indium held by the NDSC was sold in December 1998 (Brown, 2001b).
As of June 20, 2011, SMG had taken delivery of $6.1 \mathrm{t}$ of a total purchased amount of $11.1 \mathrm{t}$ of indium metal and was expecting to purchase an additional $14.5 \mathrm{t}$ of indium by the end of 2012 (SMG Indium Resources Ltd., undated).

\section{Consumption}

From 1990 through 2010, the average annual consumption of indium (excluding indium contained in net imports of semifabricated products or manufactured consumer products) in the United States was 20.5 percent of primary production of indium metal worldwide. If imported consumer products (containing indium) were included, then the percentage of primary indium produced worldwide that was consumed by the United States would have been 37 percent in 2008 and 36 percent in 2009 (Euromonitor International, 2008; Tolcin, 2011). Figure 4 shows the consumption of indium metal (excluding indium contained in imported consumer products) in the United States from 1979 through 2010.

Consumption of indium metal in the United States grew steadily from 1979 to 2000 at about 7.4 percent compounded 
annually. However, the growth rate from 2000 through 2008 was much greater, about 11 percent compounded annually. In 2009 and 2010, growth ceased largely owing to general economic conditions. Market concerns about indium priced at $\$ 10,000$ per kilogram have receded as reflected by commodity prices that declined in general during 2009 and 2010 (Azom, 2009).

The end use that takes the largest share of indium end-use markets is ITO mainly in the form of coatings for FPDs, which provides both electrical conductivity and optical transparency. In general, the thickness of ITO substrates is measured in nanometers. Sputtering is one method used to apply the ITO to glass or plastic. These coated thin-film transistors are used to manufacture liquid crystal displays (LCDs), which are further assembled as components in computers, mobile phones, televisions, and handheld electronic devices (SMG Indium Resources Ltd., 2011).

Thin films of ITOs are commonly deposited on surfaces by electron beam evaporation, physical vapor deposition, or a range of sputtering deposition techniques. Production of ITO thin-film coatings accounted for approximately 56 percent of primary production of indium worldwide (SMG Indium Resources Ltd., 2011, p. 54).
Potential substitutes and alternatives to indium (SMG Indium Resources, Inc., 2011) include the following:

- antimony-tin oxide (ATO) coatings, which have been successfully annealed to LCD glass but have the potential drawback that antimony is considered toxic

- carbon nanotubes, which are being heavily researched and have advantages compared with ITOs, such as relative lower cost, compatibility with flexible substrates, and improved performance in certain applications, including flexible displays, solar cells, and touch screens

- graphene, which is another substitute for ITO that works well in laboratories, especially for touch screens and flexible displays; some laboratories actually manufacture graphene by growing it on an indium substrate

- poly(3,4-ethylenedioxythiophene) (PEDOT), which has also been developed as a substitute for ITO in flexible displays and organic LEDs

- zinc-oxide, of which a more adhesive nanopowder has recently been developed to replace ITO in LCDs

Although graphene, carbon nanotubes, PEDOTs, and the other transparent conductive oxides may be viable alternatives,

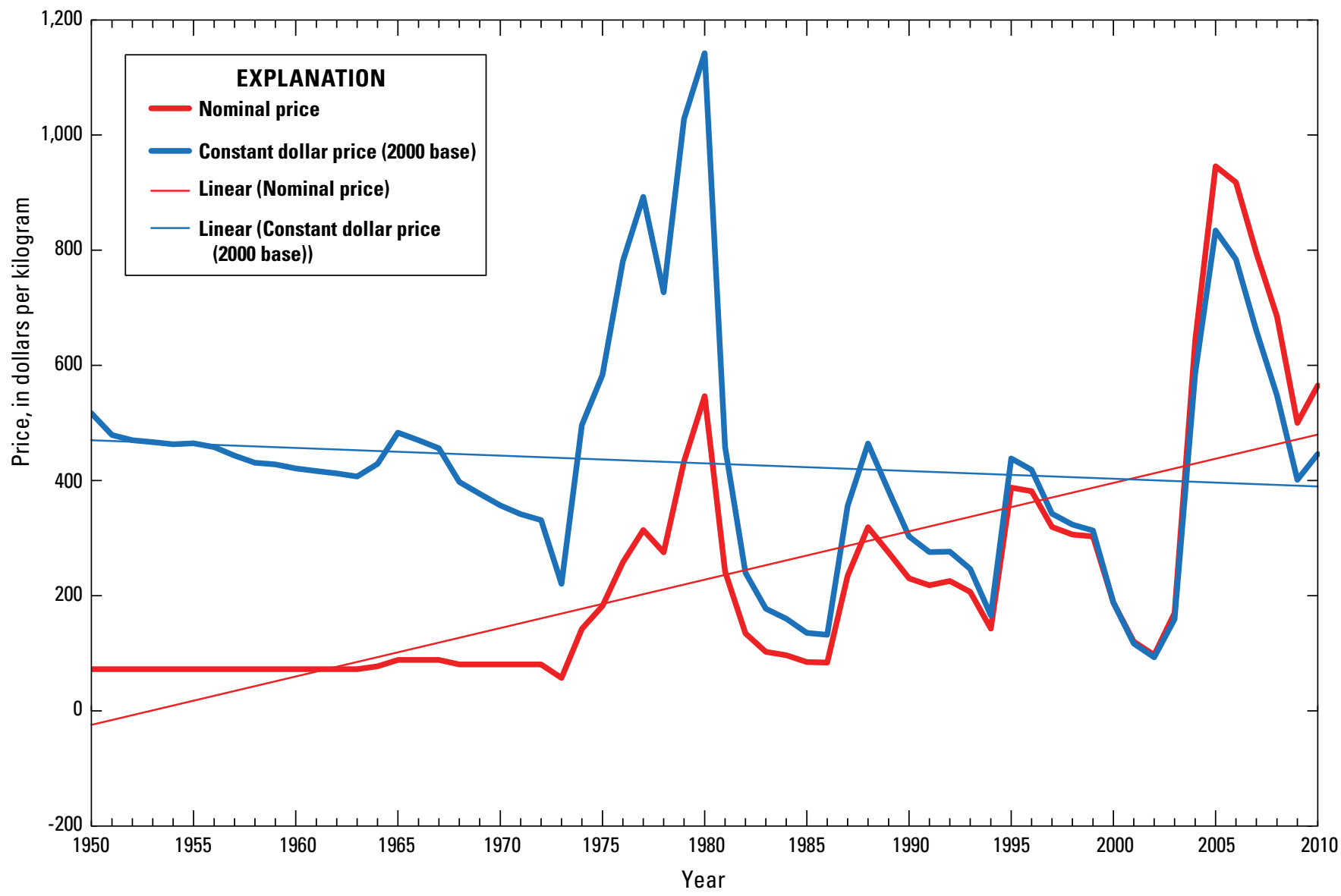

Figure 5. Chart showing U.S. prices of indium metal from 1950 through 2010. Values are in dollars (nominal and constant at 2000 values) per kilogram of indium metal. Data are from DiFrancesco and others (2010) and Bureau of Labor Statistics (2011). 
it remains unknown if manufacturers of special materials can successfully commercially produce enough of these specialty materials to supply the industry. Furthermore, it is not known how well these new materials will perform for the long term in consumer products (SMG Indium Resources Ltd., 2011, p. 54). If any of these materials meet the production and performance challenges stated and can compete in terms of price, then the future demand for indium in the transparentconductor market could decrease.

ITO for FPDs accounts for 56 percent of indium consumption. About 14 percent of the total end use of indium is as metal and alloy shapes, solders, and pastes. Indium solder alloys are lead free and can substitute for lead-and-tin solders where there are concerns about lead toxicity. The remaining 30 percent of indium is used for electronic and miscellaneous applications (24 percent) and as thermal interface material (6 percent) (Indium Corporation of America, 2011).

Some indium compounds - such as indium antimonide, indium nitride, and indium phosphide - are semiconductors that are used in the solar energy industry. Copper indium gallium diselenide (CIGS) is a semiconductor material used in high-efficiency photovoltaic cells in the form of thin-film photovoltaic cells. In solar cells, ITO is usually used as the anode where it is particularly suited for increasing the conversion efficiency of the cells because of its advanced light trapping capability, high transparency, and low resistivity. The thinfilm photovoltaic cell is lightweight, can be applied on uneven surfaces, and can be rolled up when not in use (SMG Indium Resources Ltd., undated). LEDs use a layer of indium and gallium in a ratio of 1:8. Worldwide indium use in LEDs could reach $40 \mathrm{t}$ by 2016 (Indium Corporation of America, 2011).

\section{Prices}

The market prices of indium are affected by rates of reclaiming and recycling of indium, rates of production of indium as a byproduct from mining of zinc, the economic condition of the zinc industry, and demand from end users of indium and ITO; prices of indium may also be affected by a variety of unpredictable international economic, monetary, and political considerations (SMG Indium Resources Ltd., undated). Indium prices are affected by spot sales to some degree but more closely pertain to large-volume contracts between producers and semifabricators.

Between 1988 and 2010, indium prices have averaged $\$ 381$ per kilogram (in constant 2000 dollars). However, prices have been quite volatile (deviating from the average by as much as \$199 per kilogram), reflecting short-term imbalances of supply and demand (fig. 5).

The spike in the price of indium in the late 1970s and early 1980s was likely owing to increasing demand for indium in nuclear reactors, the construction of which was experiencing growth at that time. World production of indium peaked at $50 \mathrm{t}$ in 1980, the same year that the price of indium reached its highest level, of the maximum price for indium), and again in 1982, when indium prices fell to levels last seen before the price of indium started increasing in 1974 (DiFrancesco and others, 2010).

From 1975 through 2010, indium prices have a steady peak-to-peak and trough-to-trough cycling frequency of about 8 years. From a price peak in 1995 to a price trough in 2002, the decline in indium prices was attributed to such factors as stagnant markets for FPDs in 2001 and 2002, oversupply from Chinese production, cost-competitive recycling, and fears of Ukrainian stockpile releases (Brown, 2001b, 2002, 2003). Prices for indium began to rise again in 2003 and 2004 driven by a large imbalance between supply and demand. The demand for ITO for use in LCDs grew, especially in Japan and the Republic of Korea, and there was growth in demand for low-melting-point indium in China. Production of indium was lower than in 2002 because of shortages of raw material in China and the closure of primary production facilities in France (George, 2005; Carlin, 2006). In 2005, indium prices peaked at twice the previous peak of 1995 after the accumulation of large stock levels based on speculation that there would be supply shortages occasioned by the closure of environmentally underperforming smelters in China (Tolcin, 2007). From 2005 through 2010, indium prices have declined, but are still higher than the peak of 1995 because of continued strong demand for FPDs, even when facing a worldwide economic recession. Secondary production of indium worldwide increased significantly from 2005 through 2007 and by 2007 accounted for a greater share of production of indium than primary production (U.S. Department of Energy, 2010).

\section{Recycling}

Recycling of indium has increased in recent years to the point where indium recycling accounts for a larger porion of the supply of indium than primary refinery production (SMG Indium Resources Ltd., undated). The greatest portion of indium recycling involves recovery from the inefficient ITO sputtering process. Only about 30 percent of an ITO sputtering target is effectively deposited as quality substrate material. The remaining 70 percent consists of the spent ITO target, grinding sludge, and after-processing residue left on the walls of the sputtering chamber. This recovery process used to be about 60 to 65 percent efficient, but research is directed toward achieving recovery levels of 90 percent (Tolcin, 2011).

Typically, end users (for example, FPD manufacturers) establish contracts directly with recyclers. Pursuant to such contracts, the end user supplies the recycler with scrap indium, and the recycler refines and then returns the recovered indium to the end user. Under the terms of the contract, recyclers cannot sell the recycled indium to anyone other than the end user who supplied the scrap indium. This type of scrap is generally called prompt scrap, and the ITO recycling loop, from collection of scrap to production of secondary materials, takes less than 30 days (Tolcin, 2011). Recent research efforts have been directed toward further improving the recovery of recirculating 
indium-containing materials in the sputtering process and finding ITO coating process alternatives to sputtering.

More challenging is the recovery of indium from consumer products that reach the end of their life cycle after serving consumers; this category includes old scrap, particularly old FPDs in computers, electronic devices, and televisions, and indium-containing semiconductor materials in solar cells. Sharp Corporation (Japan) has succeeded in recycling indium from LCD panels. The panels are crushed into cullet (small chips) and then treated in an acid solution to dissolve the ITO, from which the indium is selectively recovered (Kawaguchi, 2006). Solar cells have a service life ranging from 20 to 30 years, so the amount of waste currently generated from this source is small. Presently, CIGS semiconductors are used in only a fraction of the currently active solar arrays, which will not be a subject of recycling concern for many more years. However, research has begun to address the potential for recovery of indium from these future applications at end-oflife (Nickdel, 2009).

\section{Outlook}

The use of ITO in LCDs is expected to remain the major market for indium and will likely continue to drive growth in indium consumption (PR Newswire, 2010). Photovoltaic cells for solar applications are a newer and perhaps faster growing application in terms of the numbers of new solar installations. However, there remains significant uncertainty about growth rate scenarios and the technologies that will be involved. Projections by AIM Specialty Materials (2011) expect growth rate for global primary consumption of indium for photovoltaic cells to be more than 15 percent per year from 2009 through 2013. Consumption of indium in ITO applications is expected to grow at a rate of 17 percent per year, while solar applications for indium could increase by nearly 40 percent per year, albeit from a much smaller base level than the amount recycled from ITO. Even if solar applications were to be removed from the projections owing to the uncertainty surrounding them, demand for primary indium would still be projected to grow at about 13 percent per year.

Indium Corporation of America (2011) projected growth in two market segmentse for indium (current as of April 2011). LCD panel demand was expected to grow from about 540 million units in 2009 to about 900 million units in 2014, with compound annual growth (2009-2014) being 14 percent for notebooks, 13 percent for televisions, 4 percent for computer monitors, and 1.5 percent for other applications in the LCD market segment. The photovoltaic market was projected to be equivalent to about 43 gigawatts $(\mathrm{GW})$ of rated electrical capacity in 2016, about four times the total produced in 2009, and the CIGS share of that market was projected to grow from 2 percent to 12 percent, which equates to a CIGS-driven consumption of $225 \mathrm{t}$ of indium in 2016. Finally, consumption of indium in LEDs, an emerging market for indium, could reach $15 \mathrm{t}$ by 2013 .

\section{References Cited}

AIM Specialty Materials, 2011, Home page: AIM Specialty Materials, accessed November 3, 2011, at http://www.aimspecialty.com/Home.aspx.

Alfantazi, A.M., and Moskalyk, R.R., 2003, Processing of indium-A review: Minerals Engineering, v. 16, no. 8, p. 687-694, accessed [by subscription] November 9, 2011, at http://www.sciencedirect.com/science/article/pii/ S0892687503001687.

Azom, 2009, Indium tin oxide and alternative transparent conductor markets report available in March: Azom, February 11, accessed November 21, 2011, at http://www.azom.com/ news.aspx?newsID=15582.

Brown, R.D., Jr., 1997, Indium: U.S. Geological Survey Mineral Commodity Summaries 1997, p. 80-81. (Also available at http://minerals.usgs.gov/minerals/pubs/commodity/ indium/490397.pdf.)

Brown, R.D., Jr., 1998, Indium: U.S. Geological Survey Mineral Commodity Summaries 1998, p. 80-81. (Also available at http://minerals.usgs.gov/minerals/pubs/commodity/ indium/490398.pdf.)

Brown, R.D., Jr., 1999, Indium: U.S. Geological Survey Mineral Commodity Summaries 1999, p. 84-85. (Also available at http://minerals.usgs.gov/minerals/pubs/commodity/ indium/490399.pdf.)

Brown, R.D., Jr., 2000, Indium: U.S. Geological Survey Mineral Commodity Summaries 2000, p. 82-83. (Also available at http://minerals.usgs.gov/minerals/pubs/commodity/ indium/490300.pdf.)

Brown, R.D., Jr., 2001a, Indium: U.S. Geological Survey Mineral Commodity Summaries 2001, p. 78-79. (Also available at http://minerals.usgs.gov/minerals/pubs/commodity/ indium/490301.pdf.)

Brown, R.D., Jr., 2001b, Indium, in Metals and minerals: U.S. Geological Survey Minerals Yearbook 1999, v. I, p. 37.1-37.4. (Also available at http://minerals.usgs.gov/minerals/pubs/ commodity/indium/490499.pdf.)

Brown, R.D., Jr., 2002, Indium, in Metals and minerals: U.S. Geological Survey Minerals Yearbook 2000, v. I, p. 38.138.4. (Also available at http://minerals.usgs.gov/minerals/ pubs/commodity/indium/490400.pdf.)

Brown, R.D., Jr., 2003, Indium, in Metals and minerals: U.S. Geological Survey Minerals Yearbook 2001, v. I, p. 37.137.4. (Also available at http://minerals.usgs.gov/minerals/ pubs/commodity/indium/indimyb01.pdf.)

Bureau of Labor Statistics, 2011, Consumer price index: Bureau of Labor Statistics, accessed October 25, 2011, at http://data.bls.gov/.

Callaghan, R.M., and Carlin, J.F., Jr., 2007, Indium, in Metals and minerals: U.S. Geological Survey Minerals Yearbook 2005, v. I, p. 36.1-36.5. (Also available at 
http://minerals.usgs.gov/minerals/pubs/commodity/indium/ indiumyb05.pdf.)

Carlin, J.F., Jr., 2006, Indium, in Metals and minerals: U.S. Geological Survey Minerals Yearbook 2004, v. I, p. 36.136.6. (Also available at http://minerals.usgs.gov/minerals/ pubs/commodity/indium/indiumyb04.pdf.)

DiFrancesco, C.A., George, M.W., Carlin, J.F., Jr., and Tolcin, A.C., 2010, Indium statistics, in Kelly, T.D., and Matos, G.R., 2010, Historical statistics for mineral and material commodities in the United States: U.S. Geological Survey Data Series 140, accessed December 8, 2011, at http://minerals.usgs.gov/ds/2005/140/indium.pdf.

DisplaySearch, 2009, DisplaySearch sees flat panel display growth slowing through 2015: DisplaySearch, accessed October 5, 2011, at http://www.displaysearch.com/cps/rde/ xchg/displaysearch/hs.xsl/01_27_09_displaysearch_sees flat_panel_display_growth_slowing_through_2015.asp.

Euromonitor International, 2008, What your global neighbors are buying: The New York Times, September 4, accessed September 14, 2011, at http:/www.nytimes.com/interactive/2008/09/04/ business/20080907-metrics-graphic.html.

George, M.W., 2005, Indium, in Metals and minerals: U.S. Geological Survey Minerals Yearbook 2003, v. I, p. 36.136.6. (Also available at http://minerals.usgs.gov/minerals/ pubs/commodity/indium/indiumyb03.pdf.)

ICF International, 2011, Electronics waste management in the United States through 2009: U.S. Environmental Protection Agency 530-R-11-002, May, 49 p., available at http://www.epa.gov/osw/conserve/materials/ecycling/docs/ fullbaselinereport2011.pdf.

Indium Corporation of America, 2011, Sustainability of indium and gallium in the face of emerging markets: Indium Corporation of America presentation, April 21, 26 p., accessed November 29, 2011, at http://www.indium.com/ _dynamo/download.php?docid=1646.

Jasinski, S.M., 1990, Indium: U.S. Bureau of Mines Mineral Commodity Summaries 1990, p. 82-83.

Jasinski, S.M., 1991, Indium: U.S. Bureau of Mines Mineral Commodity Summaries 1991, p. 76-77.

Jasinski, S.M., 1992, Indium: U.S. Bureau of Mines Mineral Commodity Summaries 1992, p. 86-87.

Jasinski, S.M., 1993, Indium: U.S. Bureau of Mines Mineral Commodity Summaries 1993, p. 84-85.

Jasinski, S.M., 1994, Indium: U.S. Bureau of Mines Mineral Commodity Summaries 1994, p. 84-85.

Jasinski, S.M., 1995, Indium: U.S. Bureau of Mines Mineral Commodity Summaries 1995, p. 80-81.

Jorgenson, J.D., and George, M.W., 2005, Mineral commodity profile-Indium: U.S. Geological Survey Open-File Report
2004-1300, 20 p., accessed March 22, 2011, at http://pubs.usgs.gov/of/2004/1300/2004-1300.pdf.

Kawaguchi, Yohei, 2006, Coming full circle: Recycling Magazine, accessed November 22, 2011, at http://www.recyclingmagazin.de/rmeng/ news_detail.asp?ID=10640\&MODE $=202 \& N S=1$.

Lahtinen, M., Svens, K., Haakana, T., and Lehtinen, L., [undated], Zinc plant expansion by Outotec direct leaching process: Outotec, accessed November 14, 2011, at http://www.outotec.com/38580.epibrw.

Metal Bulletin, Ltd., 2009, China's indium prices surge on stockpiling plans: Metal Bulletin, June 9, accessed November 16, 2011, at http://www.metalbulletin. com/Article/2229241/Chinas-indium-prices-surge-onstockpiling-plans.html.

Mikolajczak, Claire, 2009, Availability of indium and gallium: Indium Corporation, accessed April 12, 2011, at http://www.indium.com/_dynamo/ download.php?docid=552.

Nickdel, Sina, 2009, Recycling copper indium selenide from solar cells: Göteborg, Sweden, Chalmers University of Technology Master's thesis, 31 p., accessed June 13, 2011, at http://www.chalmers.se/chem/SV/amnesomraden/ industriell/genomforda-projekt/recycling-copper-indium/ downloadFile/attachedFile_f0/Recycling_copper_indium selenide_from_solar_cells.pdf?nocache $=1294144969.37$.

PR Newswire, 2010, LCDs remain the driving force of the indium market: PR Newswire, January 31, accessed November 29, 2011, at http://www.prnewswire.com/ news-releases/lcds-remain-the-driving-force-of-the-indiummarket-114921939.html.

RareMetalsInvesting, 2011, Japan hoarding indium? 2010 import statistics revealing: Seeking Alpha blog, February 27, accessed February 14, 2012, at http://seekingalpha. com/instablog/868319-raremetalsinvesting/142352-japanhoarding-indium-2010-import-statistics-revealing.

SMG Indium Resources Ltd., 2011, Prospectus: U.S. Securities and Exchange Commission Registration No. 333-165930, May 4, 128 p., accessed May 31, 2011, at http://www.smg-indium.com/Docs/SMG_Indium_Final_ IPO_Prospectus.pdf.

SMG Indium Resources Ltd., [undated], Management's discussion and analysis of financial condition and result of operations: U.S. Securities and Exchange Commission, accessed November 16, 2011, at http://google.brand.edgar-online.com/EFX_dll/EDGARpro. dll?FetchFilingHtmlSection 1 ?SectionID=8001236-85214118054\&SessionID=XD0wFF7Jkd7vQm7.

Schwarz-Schampera, Ulrich, and Herzig, P.M., 2002, Indium - Geology, mineralogy, and economics: Heidelberg, Germany, Springer, 257 p. 
Tolcin, A.C., 2007, Indium, in Metals and minerals: U.S. Geological Survey Minerals Yearbook 2005, v. I, p. 36.1-36.5. (Also available at http://minerals.usgs.gov/minerals/pubs/ commodity/indium/indiumyb05.pdf.)

Tolcin, A.C., 2008, Indium, in Metals and minerals: U.S. Geological Survey Minerals Yearbook 2006, v. I, p. 35.1-35.5. (Also available at http://minerals.usgs.gov/minerals/pubs/ commodity/indium/myb1-2006-indiu.pdf.)
Tolcin, A.C., 2009, Indium, in Metals and minerals: U.S. Geological Survey Minerals Yearbook 2007, v. I, p. 35.1-35.8. (Also available at http://minerals.usgs.gov/minerals/pubs/ commodity/indium/myb1-2007-indiu.pdf.)

Tolcin, A.C., 2011, Indium, in Metals and minerals: U.S. Geological Survey Minerals Yearbook 2009, v. I, p. 35.1-35.5. (Also available at http://minerals.usgs.gov/minerals/pubs/ commodity/indium/myb1-2009-indium.pdf.) 


\section{Appendix 1.-Explanation of Flow Diagrams}

The flow into "supply of indium for semifabrication" from "imports of metal, wastes, and powders" (140 tons (t) in 2008 ) is reported annually in volume I of the U.S. Geological Survey Minerals Yearbook.

The flow of "net exports and stock changes" ( $8.9 \mathrm{t}$ in 2008) is what is left after all other flows are accounted.

U.S. consumption of semifabricated indium (130 $\mathrm{t}$ in 2008 ) is reported annually in volume I of the U.S. Geological Survey Minerals Yearbook.

The flows to consumption (130 $\mathrm{t}$ in 2008) have been split 56 percent $(73 \mathrm{t}$ in 2008) to "indium as ITO powder for flat panel display manufacture" and the remaining 44 percent (57 $t$ in 2008) to "indium contained in other products" based on information provided by Indium Corporation of America as to market shares for each indium end use.

The flows into "indium as ITO powder for flat panel display manufacture" have two components; the one includes material from "metal, waste, and powders" imports for consumption ( $78 \mathrm{t}$ in 2008), and the other, includes the material available from the constant return (reclamation) loop from the ITO sputtering process (46 $\mathrm{t}$ in 2008).

The sputtering process is 30 percent efficient. So, if 73 $t$ (in 2008) of indium reaches the consumption stage, then roughly $51 \mathrm{t}$ (70 percent of $73 \mathrm{t}$ ) goes to a reclaiming process. Assuming this process is 90 percent efficient, then $46 \mathrm{t}$ reenters FPD manufacturing, and $5.1 \mathrm{t}$ is lost.

Of the worldwide primary production of $600 \mathrm{t}$ of indium in 2008 (reported from volume I of the U.S. Geological Survey Minerals Yearbook), $130 \mathrm{t}$ is $470 \mathrm{t}$ of indium is unassigned. Assuming the 56 percent ratios for the percentage of indium in FPDs, $300 \mathrm{t}$ of this unassigned material in FPD products (computer monitors displays, handheld electronics, and televisions) in 2008. The United States accounted for 37 percent of the world's consumption of primary indium, leading to $90 \mathrm{t}$ of indium contained in FPD products imported and total U.S. consumption of $220 \mathrm{t}$ of indium in 2008. Of the 220 $\mathrm{t}$ of total indium consumed in the United States in 2008, $170 \mathrm{t}$ was as ITO used in FPDs. 
Prepared by the Pembroke and Reston Publishing Service Centers.

For more information concerning this report, contact:

Director

U.S. Geological Survey

National Minerals Information Center

12201 Sunrise Valley Drive

Reston, VA 20192

nmicrecordsmgt@usgs.gov

or visit our Web site at

http://minerals.usgs.gov/minerals/. 
